\title{
Internationalization Process and Technological Capability Trajectory of Iguaçu
}

\author{
Rafael Kuramoto Gonzalez', Sieglinde Kindl da Cunha²
}

\begin{abstract}
This article focuses on the influence of the internationalization process in the evolution of technological capability. This implication was studied in Iguaçu between 1967 and 2009. To achieve the proposed goal it was used the Internationalization of Brazilian Export Producer Companies Model, built by Kraus (2006) and the Model of Technological Capabilities in Companies of Emerging Economies, built by Figueiredo (2004). The study found that different stages of internationalization require different functions and different levels of technology. The discussion proposed by this paper found a close association between the process of internationalization and the development of technological capability in the company studied. It can be concluded that for companies of Soluble Coffee to conquer, reach and remain competitive in international markets it should engage efforts to build diverse organizational skills, alliances and technological capabilities.
\end{abstract}

Keywords: internationalization; technological capability; soluble coffee; technological trajectory; emerging companies; innovation; internationalization path

'EBAPE, Getulio Vargas Foundation (FGV), Praia de Botafogo Street, 190, $4^{\circ}$ Floor - Botafogo, Rio de Janeiro - RJ, Brazil, 22250-900, (55) 2I 255I-5195,rafael_k_gonzalez@yahoo.com.br

2PPGADM, Federal University of Paraná (UFPR), Pref. Lothario Meissner Street, 632, $2^{\circ}$ Floor - Jardim Botànico, Curitiba-PR, Brazil, 802I0-170, (55) 4I 3360-4365, skcunha2I@gmail.com

ISSN: 07 I8-2724. (http://www.jotmi.org)

Journal of Technology Management \& Innovation @ Universidad Alberto Hurtado, Facultad de Economía y Negocios. 


\section{Introduction}

It is perceived in the world economy that the level of competitiveness has been accelerated by global markets. To remain competitive and conquer markets, companies must seek constant improvements in their products, processes, services and strategies. In the era of knowledge economy, the cycle of innovation has increased its speed and demands something more from the companies. To survive and have opportunities to thrive, organizations must seek new markets and build capabilities in order to compete with more prepared global players.

Multinational corporations in a capitalist economy, assuming the role of main actors as generators and multipliers of technological knowledge put into practice, dictate the pace and direction of global technological frontier in different industrial sectors. The search for international markets is necessary so that organizations can expand their markets, increase their financial returns, increase competitiveness, leverage international networks, acquire knowledge and survive.

In the knowledge economy has been proved that knowledge is a crucial asset for economic development, and it was also ascertained the importance of understanding organizations as agents of economical, technological, environmental and social development . In this context of global integration, the accumulation of skills to select, adapt and / or develop technologies is crucial to staying competitive (Figueiredo, 200I). The main objective of this research is to analyze the influence of the internationalization process in the path of accumulation of technological capabilities of lguaçu. The specific objectives are: (a) characterize its internationalization process, (b) Identify its development of technological capability, (c) Identify the relationship between its internationalization process and its technological development capability.

The authors of this paper recognize that there are numerous theoretical and empirical contributions in the international literature about Internationalization process and Technological Capabilities. Both literatures analyze the importance of knowledge for the companies build competitive advantages and operate in the international market.

First, the literature about Internationalization process was focus of various authors. According to Benito and Gripsrud (1992), Anderson (2000) and Andersen and Buvik (2002) the internationalization literature can be divided in two approaches: Economic and Behavioral (Processual). The Economic approach is composed primarily by four theories: Product Cycle Theory by Vernon (1966 and 1979); Market Power Theory by Hymer (1976); Internalization Theory by Buckley and Casson (1988) and Rugman (1980); and Ecletic
Paradigm or OLITheory by Dunning (2000 and 200I).These theories are based in economic criterias and rational thinking (Did and Carneiro, 2006). In another hand, the Behavioral approach was launched by the Uppsala Model, constructed by Johanson and Wiedersheim-Paul (1975) and Johanson and Vahlne (1977 and 1990). The Uppsala Model study the internationalization phenomenon from the behavioral firm perspective of Cyert and March (1963) and Aharoni (1966) together with the rational limited pesperctive of Simon (1965). Both Economic and Behavioral perspective was studied and developed by theorists analyzing firms in advanced economies and do not consider the idiosyncrasies of emerging companies. Therefore, these theoretical approaches demonstrate limited to understand the internationalization process of firms that operates in emerging economies such as the Brazilian economy. In order to fill this gap, this paper consider the Internationalization model built by Kraus (2006) as a alternative to understand the internationalization path realized by lguaçu. It's reinforced that Kraus' Model is inspired by the Uppsala Model and theoretically does not differ from the Behavioral approach.

Finally, the literature about Innovation and Technological Capabilties suffers from the same "syndrome". Theories such as Dynamic Capabilies Theory by Teece et al (1997), Organizing Firm-specific Competences by Pavitt (199I), The Core Competence Theory by Prahalad and Hamel (1990), and others (lansiti and Clark, 1994 for example) focus their anal$y$ sis in industrial organizations that operates near or in the international technological frontier, in other words, these firms already hold the necessary knowledge and technological capabilities to generate innovations at international level. These companies are concerned to differentiate themselves from global competitors and not to construct technological capabilities. Therefore, this paper uses a different perspective. The framework used by the authors to understand the technological trajectory performed by lguaçu is similar to other studies in emerging economies of different industries such as Software (Rousseva, 2008), LCD-LED (Xie and Wu, 2003; Xie, 2004; Chuang, 2008), communications (Marcelle, 2005), electronics (Kim, 1997; Ariffin and Bell, 1999; Ariffin and Figueiredo, 2004; Hobday and Rush, 2007; and others), manufacture (Karaoz and Albeni, 2005; Chen, 2009; Nan, $20 \mathrm{II}$ and others). All this studies focus high technologybased industries, and the international literature presents scarcity of empirical evidence in low-medium technologybased industries. A few examples could be addressed by the study developed by Dantas and Bell (2009 and 20II) in the petrochemical field, Reichert et al (20II) in the plastic field, and finally, Scott-Kemmis (1988) and Figueiredo (2010) in the forestry, pulp and paper field. Therefore, this study is a attempt to add empirical evidence from coffee soluble industry for the understanding of technological trajectory of low-medium technology-based industries. 
To achieve the objectives established by the research the article is divided into four parts. The first section presents the theory of internationalization and technological capability used for the analysis of the case study of Iguaçu. In the second block is shown the Description Model of Technological Capability for Soluble Coffee Industries built for the research. The third part presents the analysis of the data and the fourth and last section of the article concludes with final remarks.

\section{I.Theoretical Empirical Review}

This section will present concepts on internationalization and technological capability. Also the models used are explained in the article: Internationalization Model built by Kraus (2006), Technological Capability Model built by Figueiredo (2003) and finally the Description Model of Technological Capability for Soluble Coffee Industries built by the authors for this research.

\section{I.I Internationalization}

Authors like Johanson and Vahlne (1977), Lall (1980) and Oviatt and McDougall (1999) consider internationalization as an evolutionary process, which occurs gradually, over the time and the firm expand its international operations. Molero et al (1998) focus the intellectual capital and knowledge licensing in international projects. Prashantam (2005) emphasize the importance of internationalization to the firm competitiveness, while Kogut (2002) and Leonidou et al (2002) consider the great importance of the external agents and the ambient to understand why and how the firm realized internationalization.

However, in this paper, internationalization can be understood as the involvement process in international operations and it relates to activities such as foreign trade, capital flows, technology transfer, information flow and data, alliances, mergers, acquisitions, (FDI) Foreign Direct Investment among others (Welch and Luostarinen, 1988). Also, Kraus (2006, p 60) understands internationalization as "a process that takes place over time, in which the producer exporter expands his involvement and commitment to international operations."

For this paper, the authors considered the Internationalization Model built by Kraus (2006) as the most appropriate to understand the internationalization process of an organization industry of an emergent economy. The Model of Internationalization of Brazilian Producer Exporter Companies was built by the study of Kraus (2006), who set up an approach based on studies of national and international literature with the intention of adapting it to the Brazilian reality. The author considers that a model with explanatory power to represent the situation in Brazil is supported by the evidence that in this country the vast majority of companies become international upon developing exports (KRAUS, 2006, p. 34).

According to Kraus (2006), the model features four gradual steps, which represent the producer exporter company's commitment in operations abroad. Here the four steps: (i) pre-engagement, (ii) passive involvement, (iii) active involvement and (iv) committed involvement. This model can be better understood with Figure I. Kraus (2006) comments on his work that in each stage (pre-engagement, passive engagement, active involvement, commitment and involvement) there are stages that can be considered as sub-steps. The author explains each step as follows:

Step of Pre-engagement - The organization is focused entirely on the local market it considers safe and familiar. Most Brazilian companies belong here, but may in the future operate abroad. This step consists of: Stage Non-Export and Stage Pre-Export.

Step of Passive Involvement - In this stage the company is involved with its first export activities; it already has a structure, contacts and has exhibited their products at trade shows or fairs. This step consists of: Stage Irregular Exporter and Stage Passive Exporter.

Step Active Involvement - In this stage the company becomes aware of its passivity and shifts its production focus for the market. This step consists of: Stage Pre-Active Exporter and Stage Active Exporter.

Step Committed Involvement- In this stage the company operates in several markets and seeks to adequate itself to the tastes and habits of its consumers, adapting and developing specific products and after-sale services. It is also at this stage that the company finds opportunities with the establishment of offices and production units.

\section{I.2 Technological Capability}

There are various definitions of technological capability found both in national and international literature. Bell et al (1984) introduce the concept of "Industrial Infant" and "Industrial Maturity". Penrose (1959) was the first to consider the firm as a resource agglomerate. She introduce the term "Technological Base" do describe the set of capabilities and assets that constitutes the core of knowledge and skills that a firm masters and on which the firm develops. Katz (1976) focus the innovation process, where technological capability is an "inventive activity" or an systematic creative effort in order to increase the productive capacity or to obtain new knowledge. Dahlman and Westphal (1982) formulated the 


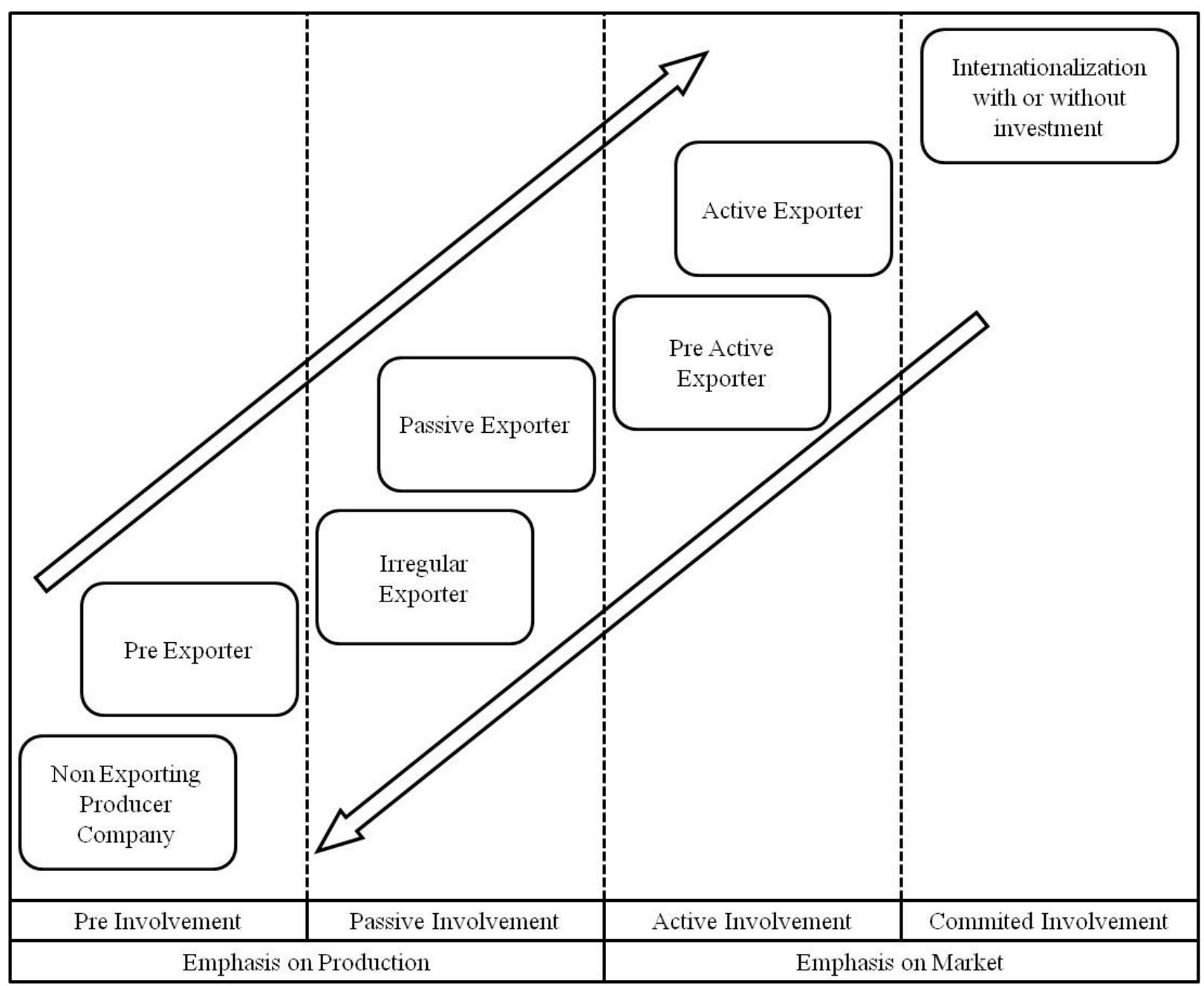

Figure I- Internationalization Model Of Brazilian Producer Exporter Companies Source: Kraus (2006, p. 35)

"Technological Domain" concept,which is considered analogous to "technological capability" concept.

The term "technological capability" was improved over the years by Bell (1982), Westphal et al (1984), Scott-Kemmis (1988), Enos (1991), Lall (1992), Kim (1993) and others. However, for this paper it will be we used the one developed by Bell and Pavitt (1993), who consider technological capability as the resources needed to generate and manage technological change, including skills, knowledge and experience, institutional structures and networks. The resources required to manage this technological change are allocated to individuals and organizational systems (Bell, Pavitt, 1993, 1995). Both authors distinguish "capability" and "innovative capability", considering production capability as routine capabilities, which are the skills for operational activities and production of goods and services with a certain level of efficiency, using a cluster of dimensions: skills, equipment, prod- uct specifications and production systems and organizational methods. On the other side, the innovative capability refers to the incorporation of additional and distinct features to generate and manage technological change.

Various authors engaged to construct and improve Models to understand the technological capability trajectory. We can mention six majors models that served as inspiration: Lall's Model (1992) divided in Complexity Degree and Technical Functions, Bell and Pavitt's Model (1993) based on the categories of technological capability, Kim's (1997) based in the trajectory of imitation to generation, Bell's Model (1997 apud Figueiredo 2003) which introduces the notion of gradual accumulation of new technological capabilities, Hobday's Model (1995) which contextualize technological capabilities to emerging companies and finally, Figueiredo's Model (2003). We can argue that all these models plays an important role to understand how firms accumulate and perform 
innovation capability. For this paper, we considered that the Figueiredo's model was the most appropriate to understand the phenomenon of technological trajectory.

Figueiredo (2003) constructed a model which allows to identify and measure the technological capability-based activities that the company is able to accomplish throughout its existence. The model distinguishes two types of capabilities: Routine Capabilities, which includes the ability to use or operate a given technology, and Innovative Capability, the ability to adapt or develop new production processes, organizational systems, products, equipment and engineering projects, that is, generate and manage technological innovation.

According to Figueiredo (2003), the model is explained as follows: The columns represent the technological capabilities by function, and the lines the levels of difficulty. These categories are measured by the activities that express levels of capabilities or, in other words, the type of activity that the company is able to perform on its own at different time intervals. The model is divided into seven levels of technological capability for five functions.

\subsection{Taxonomy of Technological Capacity for Soluble Coffee}

To develop this article, we built a taxonomy of Technological Capability specific to the industrial sector of Soluble Coffee. Table I - Description Model of Technological Capacity for Soluble Coffee Industries - is divided into sets of capabilities, capabilities that are routine and innovative capabilities.

\section{Research method}

The objective of this paper is to understand the influenced of the internationalization process in the trajectory of accumulation of technological capabilities of Iguaçu. The strategy adopted to address this question was the case study.According to Yin (2005, p.32), case study is "an empirical enquiry that investigates a contemporary phenomenon within it's real-life context, especially when the boundaries between phenomenon and context are not clearly defined."

Research Strategy and Types of Evidence: The paper used an combination of multiple sources of information, such a: interviews, meetings, observation, technical documents, historical documents and reports in order to achieve more reliability and execution of methodological traingularion in case studies (Denzin, 1978; Jick, 1979; Eisenhardt, 1989; Yin, 2005).

Source of Evidence Collection Tool and Collection Process: For this research, was intervewed a group of employees that represents the "organizational memory" of Iguaçu: Industrial
Director, Supply Management, Maintanance and Logistics Manager, Quality \& Process Coordinator, R\&D Coordinator and Training \& Development Coordinator.Also was consulted two former Presidents, four former Directors, Trade Manager and International Business Manager. In order to construct the Analytical Model of Technological capabilities and Internationalization Process, was consulted four senior professor expert in Innovation and International Business and technicians from lguaçu. The interviews was realized in February-March of 2010 in loco.

\section{The Process of Internationalization of Iguaçu}

The process of internationalization of Iguaçu was divided in the seven stages presented by Kraus' model and it demonstrated that the rate of evolution was different for each stage. The speed and how they developed the process of internationalization of the company is associated with several factors such as: Trade Restrictions and Advantages, Restrictions and Technological Advantages, Restrictions and Advantages of Brazilian Legislation, Restrictions and Benefits of International Countries Law, Restrictions and Advantages of competition, Restrictions and Advantages of Alliances, Company Focus, Strategy, Historical Events, and so on.

Between 1967 and 197I the company focus on the construction of its industrial plant, acquisition of production machinery and prospect international customers, being considered by the Kraus' Model in Pre-engagement step. Between 1972 and 1975 the firm increase its knowledge about the international customer, focus to gather information about Non-Traditional Markets (All markets that not include USA, Canada and Western Europe), but the company maintain an passive position with exporting/importing agents, in other words, in the Passive step of the Kraus'Model.

From 1976 until 1996, the firm could be considered in the Active step of Kraus'Model. These two decades was used to reinforce the global position of Iguaçu in International markets such as Romania, ex-URSS, Japan, Arabic countries, Islamic countries and other.Also, the firm engaged to develop products, process, quality, strategies, human resources and costs. From 1997, the firm can be considered in the Committed Step pf Kraus'Model. The firm invested in industrial plants over the seas. The first commercial operation was the acquisition of Panfoods Co. Limited in London - UK. This unit is responsible for the commercialization of the soluble coffee in international markets. This accomplishment permit that lguaçu untie the ties with export/import agents. The first industrial operation was lauched in Turgovivisti, Romain in 2002. In 2006, Iguaçu lauched the first industrial unit to produced freeze-dried coffee. This plant is located in Palência-Spain and produces 3,6 thousand tons/year. 


\begin{tabular}{|c|c|c|c|c|c|c|}
\hline \multirow{2}{*}{$\begin{array}{l}\text { Levels of technological } \\
\text { capability }\end{array}$} & \multicolumn{6}{|c|}{ Technological function } \\
\hline & Product & Process & Equipment & Investment & R\&D & \\
\hline (1) Básic & $\begin{array}{l}\text { Soluble coffee powder } \\
\text { production under broadly } \\
\text { accepted specifications and } \\
\text { possible international market } \\
\text { supply. Prepared through } \\
\text { Spray Drying process }\end{array}$ & $\begin{array}{l}\text { Standard coordination at the } \\
\text { factory and its productive } \\
\text { absorption capability }\end{array}$ & $\begin{array}{l}\text { Equipment installation for basic } \\
\text { production of both spray and } \\
\text { lyophilized soluble coffee. }\end{array}$ & $\begin{array}{l}\text { Agreement on the location of } \\
\text { factory and offices through a } \\
\text { technical and economic } \\
\text { feasibility study. Decision about } \\
\text { the purchase of worldwide } \\
\text { quality machinery. }\end{array}$ & $\begin{array}{l}\text { Capability for technology } \\
\text { installation and technology } \\
\text { transfer absorption. } \\
\text { t Development of team projects. } \\
\text { Call for outsourced technical } \\
\text { assistance. Enhancement of } \\
\text { installed technologies. }\end{array}$ & \\
\hline (2) Renewed & $\begin{array}{l}\text { Lyophilized soluble coffee } \\
\text { production under simple } \\
\text { specifications and international } \\
\text { market supply. Prepared } \\
\text { through Freeze Drying process }\end{array}$ & $\begin{array}{l}\text { Enhanced coordination at the } \\
\text { factory. Initial implementation } \\
\text { of basic quality tools. } \\
\text { Precursory use of } \\
\text { computerized and integrative } \\
\text { systems. }\end{array}$ & $\begin{array}{l}\text { Equipment installation for } \\
\text { enhanced production of spray- } \\
\text { dried soluble coffee and } \\
\text { extract. Artesian well drilling } \\
\text { for the factory's benefit. }\end{array}$ & $\begin{array}{l}\text { Agreement on foreign capital } \\
\text { participation and development } \\
\text { of synergy for production and } \\
\text { commercial boost. }\end{array}$ & $\begin{array}{l}\text { First R\&D own initiatives. } \\
\text { Capability for development and } \\
\text { installation of new technologies. } \\
\text { Creation of a bureau } \\
\text { specialized in new technologies } \\
\text { and technical assistance facility. }\end{array}$ & 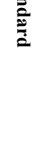 \\
\hline (3) Extra basic & $\begin{array}{l}\text { Production of various types of } \\
\text { soluble coffee under moderate } \\
\text { specifications and large } \\
\text { recognition in international } \\
\text { markets under the trademark } \\
\text { Cia Iguaçu. }\end{array}$ & $\begin{array}{l}\text { Small but period adaptations in } \\
\text { the factory's production } \\
\text { processes. Implementation of } \\
\text { basic quality tools and new } \\
\text { organizational techniques such } \\
\text { as JIT, Kanban, TQM among } \\
\text { others. }\end{array}$ & $\begin{array}{l}\text { Equipment installation for } \\
\text { enhanced production of } \\
\text { lyophilized soluble coffee. } \\
\text { Autonomous technical } \\
\text { equipment maintenance. }\end{array}$ & $\begin{array}{l}\text { Agreement on investments in } \\
\text { the improvement of the existing } \\
\text { financial asset and in the } \\
\text { development of new assets } \\
\text { which may boost the } \\
\text { production capability as well as } \\
\text { the production system and } \\
\text { product portfolio. }\end{array}$ & $\begin{array}{l}\text { Formal establishment of own } \\
\text { R\&D department. Creation of } \\
\text { projects in Pilot Cell } \\
\text { Production, chemical } \\
\text { laboratories and design } \\
\text { laboratories. }\end{array}$ & \\
\hline (4) Pre interme diate & $\begin{array}{l}\text { Coffee extract and oil } \\
\text { production under complex } \\
\text { specifications and recognition } \\
\text { in international markets. } \\
\text { Prepared through } \\
\text { cryoconcentration process }\end{array}$ & $\begin{array}{l}\text { Systematic increment of the } \\
\text { productive capacity. Use of } \\
\text { tools for promoting safety at } \\
\text { work and environmental } \\
\text { preservation }\end{array}$ & $\begin{array}{l}\text { Equipment installation for } \\
\text { complex production of spray- } \\
\text { dried soluble coffee and oil. } \\
\text { Preventive maintenance } \\
\text { implementation. Drilling of an } \\
\text { artesian well of considerable } \\
\text { depth. }\end{array}$ & $\begin{array}{l}\text { Agreement on investment in } \\
\text { vertical and horizontal } \\
\text { companies in the same sector } \\
\text { which may increase the } \\
\text { horizontal market action and } \\
\text { the accompanying coverage of } \\
\text { strategically relevant sectors. }\end{array}$ & $\begin{array}{l}\text { Formal establishment of } \\
\text { Applied Research Department } \\
\text { in charge of presenting studies, } \\
\text { projects, products and } \\
\text { innovative solutions } \\
\text { acknowledged in the national } \\
\text { industrial segment. }\end{array}$ & \\
\hline (5) Intermediate & $\begin{array}{l}\text { Agglomerated soluble coffee } \\
\text { production under very strict } \\
\text { specifications and penetration } \\
\text { in various international markets } \\
\text { Prepared through liquid coffee } \\
\text { extract in freeze concentration }\end{array}$ & $\begin{array}{l}\text { Ongoing enhancement of } \\
\text { process. Design of automated } \\
\text { static systems. Implement of } \\
\text { integrative systems throughout } \\
\text { the factory. Attainment of ISO } \\
\text { certifications. }\end{array}$ & $\begin{array}{l}\text { Equipment installation for } \\
\text { agglomerated coffee complex } \\
\text { production and its worldwide } \\
\text { production chain. }\end{array}$ & $\begin{array}{l}\text { Agreement at international level } \\
\text { on the establishment of offices } \\
\text { in key international markets. }\end{array}$ & $\begin{array}{l}1 \text { Formal establishment of } \\
\text { Applied Research Department } \\
\text { in charge of presenting studies, } \\
\text { projects, products and } \\
\text { innovative solutions } \\
\text { acknowledged in all of the } \\
\text { nationally productive sectors. }\end{array}$ & 忢 \\
\hline (6) Upper intermediate & $\begin{array}{l}\text { Production of various types of } \\
\text { soluble coffee under high } \\
\text { standard specifications and } \\
\text { developed according to the } \\
\text { requests of international client. } \\
\text { Obtainment of new products } \\
\text { through R\&D. }\end{array}$ & $\begin{array}{l}\text { Achievement of total } \\
\text { operational system. } \\
\text { Commitment to continuous } \\
\text { innovative improvements in } \\
\text { processes through R\&D. } \\
\text { Attainment of international } \\
\text { market certifications. }\end{array}$ & $\begin{array}{l}\text { Equipment installation for } \\
\text { Lyophilized soluble coffee } \\
\text { production at international level } \\
\text { and superior environmentally } \\
\text { efficiency. }\end{array}$ & $\begin{array}{l}\text { Agreement at international level } \\
\text { with the establishment of units } \\
\text { i of production in key } \\
\text { international markets. }\end{array}$ & $\begin{array}{l}1 \text { Formal establishment of } \\
\text { Applied Research Department } \\
\text { in charge of presenting studies, } \\
\text { projects, products and } \\
\text { innovative solutions } \\
\text { acknowledged in the } \\
\text { international industrial segment. }\end{array}$ & \\
\hline (7) Advanced & $\begin{array}{l}\text { Productions of various types of } \\
\text { soluble coffee under } \\
\text { internationally acknowledged } \\
\text { specifications. Obtainment of } \\
\text { new products through world } \\
\text { class R\&D. }\end{array}$ & $\begin{array}{l}\text { f World class production } \\
\text { system. Reference in design } \\
\text { and development of new } \\
\text { processes based on world } \\
\text { class R\&D. }\end{array}$ & $\begin{array}{l}\text { Installation of industrial park at } \\
\text { international level. } \\
\text { Development of R\&D projects } \\
\text { to new equipment and } \\
\text { components. Technical } \\
\text { assistance support to other } \\
\text { companies. }\end{array}$ & $\begin{array}{l}\text { Agreement on capital transfer } \\
\text { and global market production } \\
\text { by seeking to explore } \\
\text { competitive advantages of } \\
\text { countries and regions. }\end{array}$ & $\begin{array}{l}\text { Formal establishment of } \\
\text { Applied Research Department } \\
\text { in charge of presenting studies, } \\
\text { projects, products and } \\
\text { innovative solutions } \\
\text { acknowledged in all of the } \\
\text { internationally productive } \\
\text { sectors. }\end{array}$ & \\
\hline
\end{tabular}

Table I - Description Model of Technological Capacity for Soluble Coffee Industries 
In the late 70 s, and during the 80 s and 90 s, the company went through a slower internationalization process. This is due to all the facts mentioned earlier for the conquest of new markets, seeking non-traditional markets, closer ties with new customers, loosening of relations with agents, improving its quality, and expansion of their knowledge of international markets. In the late ' 90 s, the company reaches a level of internationalization that few Brazilian companies have achieved with the establishment of investment in offices, subsidiaries and production units in foreign countries.

\section{The Evolution of Technological Capability of Iguaçu}

The technological development of Iguaçu happened differently, i.e. the accumulation of technological capabilities in the company had mixed types and speeds among the five functions studied (Product, Process, Equipment, Investment and Research \& Development - R\&D). This does not indicate that the company has had some anomaly or faced a great difficulty because of the asymmetry of the technological path; this only indicates that the company's strategy has made an effort on the accumulation of certain capacities in different periods of its history.

The company has demonstrated commitment to incremental improvement of all technological functions. According to the data obtained, it has been observed that the company, throughout its trajectory, has dealt with the Product, Process, Equipment and Investment Functions pretty much the same way. Early in its history, the company has joined effort on technology training both on Investment and Equipment Products precisely in order to create a basis so that Product and Process Functions could be developed.With the sophistication of their customers and markets, the company naturally sought efforts to improve its products and processes. In recent years, the company has lined up its efforts in these four functions and can finally focus on Technological Capability in R\&D.

The data indicate that all functions are connected to each other in a very intimate way and with direct and indirect effects on improving or inhibiting the development of others. Quite obviously, the Product Function has always depended directly on the Equipment Function, or the Equipment Function depends directly and indirectly on the Investment Function. Therefore, we can confirm that a function can play a catalytic role in joint improvement of all other functions of the company. Thus, we conclude that the company suffered a gradual increase of its technological capabilities, at first stabilizing routine capabilities so later it could focus on building innovative capacities over the years.

\section{The Influence of Internationalization Process in the Evolution of Technological Capability in Iguaçu}

With data obtained from the analysis, it is possible to show some influences from the internationalization process in the evolution of technological capabilities of Iguaçu .This occurs because the data were treated according to methods previously shown and it is possible to observe historically the relationship between landmarks in the internationalization and its impact on the company's technological path (Figure I).

The early stages of internationalization occurred only with routine technological capabilities. The first innovative capacity only occurred when the company was already in the 5 th stage of internationalization. The last two stages have a greater influence on the company's search for more complex innovative capabilities. In Stage 6 two technological frontiers were surpassed (equipment and $R \& D$ ) and in the 7 th stage occurred the last two (Product and Process).

Regarding the amount of years that the company needed to overcome the technological frontier, it took 33 years for them to operate innovative functions in Product and Process, Equipment 27 years, 14 years in investments and 29 in $R \& D$.

Regarding technological changes, the same phenomenon of early levels requiring less capacity occurred. In the first five stages of internationalization, the company went through 9 changes of capacity level, meaning $40.9 \%$ of the company's technological changes. Only in the 6th stage of internationalization, the company has undergone 8 changes of capacity level, or $36.3 \%$ of the changes. The 7 th and final stage of internationalization was responsible for 5 -level changes in capacity or $22.7 \%$ of the company's technological changes.

If we turn our attention to overcoming technological boundaries, we can observe that the Stage of Pre-Active Internationalization was responsible for one surpassing, the Investment Function. On the other hand Stage of Active Internationalization contributed so that Equipment and R \& D Functions exceeded the Technological Frontier. And in the last stage of internationalization, in Stage of Committed Involvement, there was the surpassing of Product and Process Functions.

By analyzing the changes of level and surpassing of technological frontier, it was possible to determine four major Waves of Evolution. These waves are periods of evolution in the path of lguaçu marked by the passage from one stage of internationalization to another and great impact on different technological functions. The most important was wave

ISSN: 07 I8-2724. (http://www.jotmi.org)

Journal of Technology Management \& Innovation (C) Universidad Alberto Hurtado, Facultad de Economía y Negocios. 


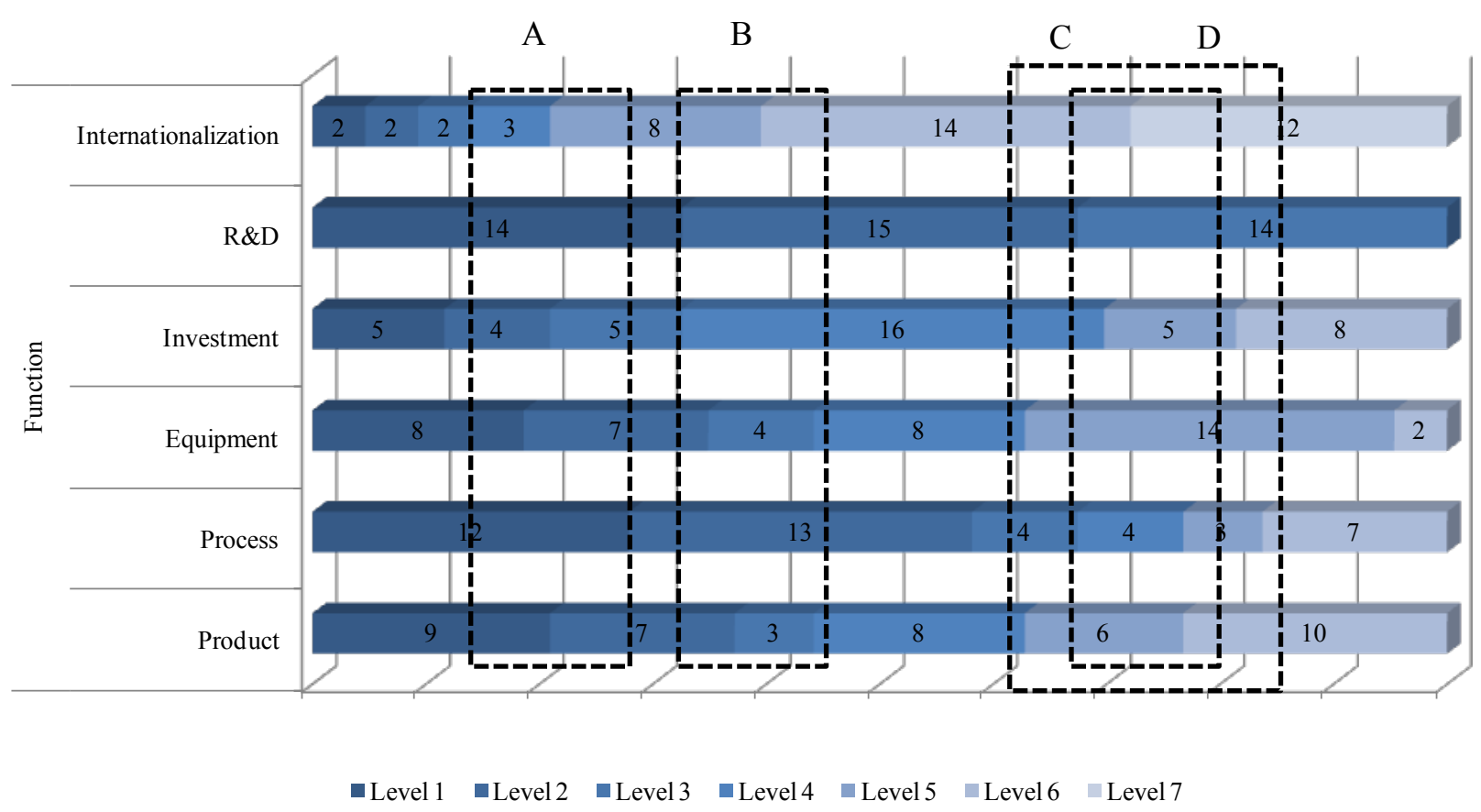

Graph I - Growth Speed and Waves of Evolution at Iguaçu

C, having occurred between 1992 and 2002, in which there were 3 Technological Frontier advances and 9 technological changes.

The most important data obtained with the visualization of the trajectories of internationalization and technological capacity are: (a) Internationalization is always ahead of the path of technological capacity of any function, (b) Function Product was the one with most varied speed, (c) Function Process only reached the other between 2002 and 2007 (d) Function Equipment had its highest growth rate in the $80 \mathrm{~s}$ (e) the investment function was the one that had the highest growth rate in the beginning of business activities and ( $f$ ) the function $R$ \& $D$ had a rate that could not follow the other in the middle 80 s.

Based on data from the technological path of Iguaçu, it is possible to determine the existence of two Technological Knots (Graph 2). Knots are periods in the Technological Path where various functions reached a prescribed level of technological sophistication in the same period. It was possible to verify that the first knot of great importance occurred in 1992, when the Investment, Product and Equipment Functions reached the Pre-Intermediate Level at the same time the company reached Stage Exporting Active.You can also point to the existence of a second Technological Knot in 2007/08, when the Function Product, Process, Equipment and Investment attained the Upper Intermediate Level few years after lguaçu had entered the Stage of Committed Internationalization.

This confirms the idea that different stages of internationalization require different functions and different levels, and, in general, it always requires a complete technological change in the company. That is, for that company to become more internationally competitive, it needs improvement before, during and after its surpassing stage.

With the interviews, it became evident that some factors are extremely important for the company to have traveled the path of internationalization as studied: experience of directors, available technology, staff, legislation, quotas and restrictions, market demands, specific customer requirements, opening and closing of markets, among others.

\section{The Implications of the Internationalization of Iguaçu of Soluble Coffee Company}

of the most crucial aspects for lguaçu to have changed its internationalization strategy occurred in 1975. At that time, Instituto Brasileiro do Café (IBC) / Brazilian Coffee Institute had imposed a quota system, limiting the amount that each company could export to traditional markets such as the USA, Canada and Western Europe. At first, it was one of the biggest barriers that the company had to overcome in order to expand its supply chain and even assure its survival. 


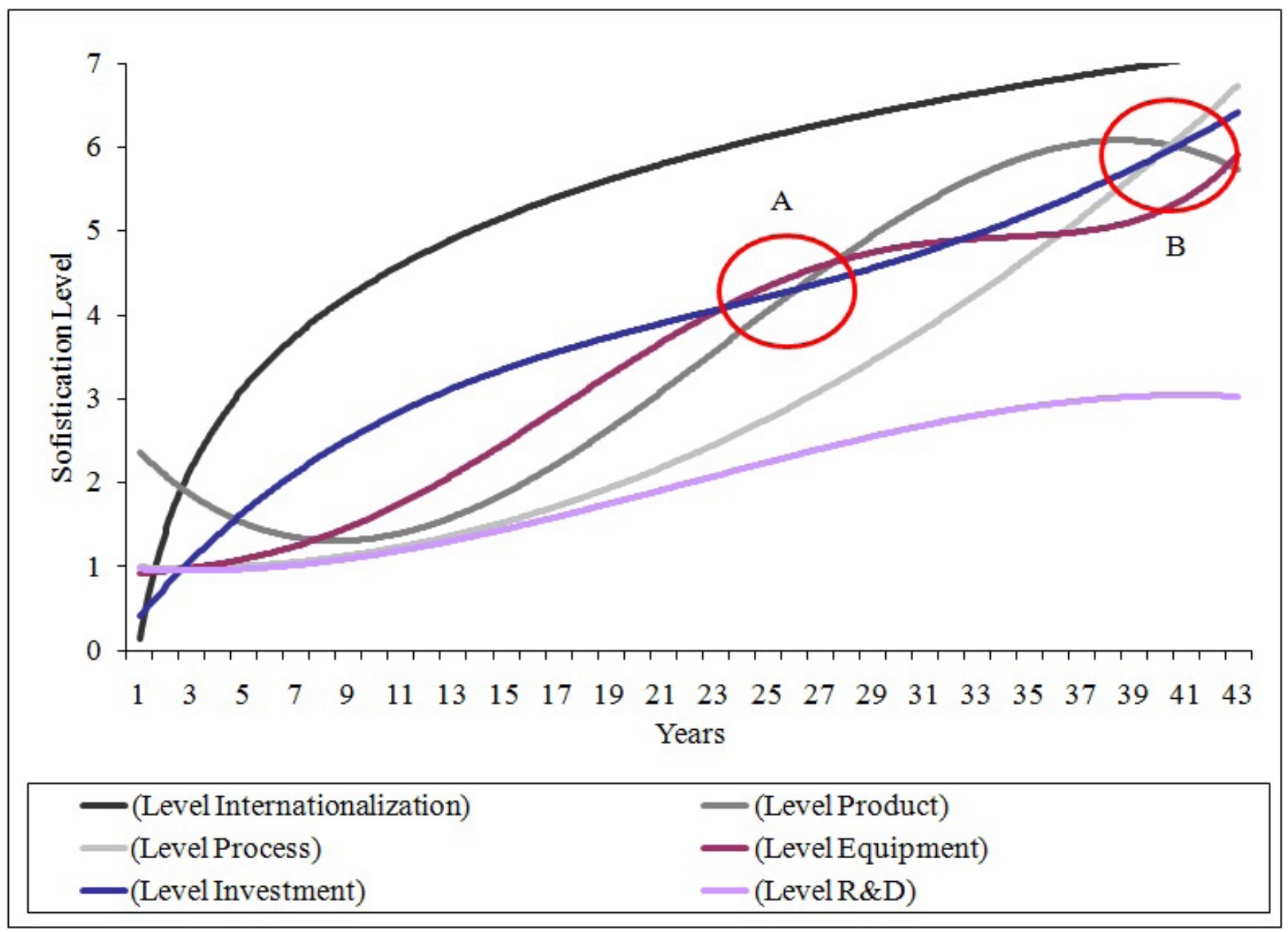

Graph 2 - Functional Evolution And Technological Knots At Iguaçu

This is how the company began to intensify its efforts to open new markets, such as the Japanese and the Soviet market. The Japanese market had a major impact on improving the technical Product Function as well as Process and Equipment Function.

Currently, the Japanese market and the countries of former Soviet Union have a strategic role for the company. It is in Romania that the company decided to install the first plant in international territory. It is in this country also the brand Iguaçu Friend competes advantageously compared with global brands of Nestlé and Kraft Foods.

Many major international markets such as the English, the Jewish and the Islamic ones demanded a radical improvement of the company in its process. For the company to access and have acceptance in these markets, Iguaçu had to adapt its policies and procedures to comply with the laws and requirements of these markets. The search for interna- tional certifications such as BRC, the Kosher and Halal occurred so that lguaçu could sell to these markets and demonstrate that its quality parameters and procedures were in accordance with such requirements.

One of the most important undertakings of lguaçu also went to the requirement of international markets. The production unit installed in Spain aims at the industrialization of coffee beans from other regions of the world. Currently the Brazilian Government prohibits the importation of other types of coffee beans grown in other regions of the world, even for industrialization. As different types of grains make up different aromas and flavors of coffee, lguaçu, to meet the requirements of international markets and specific customers, decided to install a factory in Palencia in order to process all types of coffee beans that its clients may demand.

With this information we can demonstrate that different types of technological capability (Product, Process, Equipment, Investment and R \& D) are closely intertwined with

ISSN: 07 I8-2724. (http://www.jotmi.org) 
the process of internationalization of the company. The company sought to improve its technological function in an active and passive way due to the complexity of the path of internationalization.

\section{Conclusion}

The scope of this paper was to define the discussion of the influence of the internationalization process of companies in the accumulation of technological capabilities of the coffee sector. Given these themes, we can say that the construction of theoretical models, empirical study on internationalization and technological capabilities have been fully explored. Thus, as the studies found, we identified a theoretical and empirical opportunity to address the two issues with a context for firms in emerging economies.

For this work, extensive research was needed into the historic process of internationalization of the company studied. It was also necessary to conduct a survey of the technological milestones of the company, to build a descriptive model of industry-specific technological capabilities, something that had not been done before by any other study, and to identify the evolution of technological capabilities of the company. After these two analyzes, it was necessary to find evidence that pointed to how the internationalization process influenced decision making and technological learning of the company.

It should be noted that the research methodology, theories and descriptive model were built considering only those aspects and particularities of the Soluble Coffee Industry being regarded as relevant aspects for the industry. The formation of the descriptive model and its development indicators were necessary to perform an objective and more precise analysis as to the capabilities, besides providing for future work a comparison between companies in this sector.

The article tried to use six different perspectives in order to analyze the history of the company. The methodology was the use of an Internationalization Lens and five different Lenses of Technological Capability to describe the company's evolution. The use of these different dimensions allowed visualization of commonalities and implementation, making possible to see the influence of these factors.

It is noteworthy that the soluble coffee industry is one of the rare examples of Brazilian industries to become more international and well succeed in the global marketplace, competing head to head with global competitors and dominating sophisticated consumer markets.

It can be concluded that for enterprises of soluble coffee to conquer, reach, and remain competitive in international mar- kets, they must engage efforts in order to accumulate several organizational skills, alliances and technological capabilities. That is, if the company seeks to accelerate the conquest of international markets and remain competitive in global markets it should make efforts towards seeking technical and managerial improvements of its staff and organizational network.

Efforts to complete this article made possible some contributions to the study of technological capabilities, internationalization, soluble coffee industry and industries in emerging economies.

In the section where we described the Evolution of Technological Capability of Iguaçu on its five technological functions, it was necessary to build a Descriptive Model of Technological Capability of Companies of Soluble Coffee Industry. The model constructed was shown in Table I. The model developed can serve as a tool for future research in the field of Soluble Coffee, as well as a template for building technological capabilities of other branches of industry. The possibility of contextualization of the model according to the characteristics of the technological environment of each branch of industry opens opportunities so that research in various branches of the economy be possible.

In the process of studying the influence of the Internationalization Process in the Evolution of Technological Capability of Iguaçu took place the analyzes of how the speed and growth path of the company were conducted. Reflecting on this influence, two phenomena were found, and thus, the names and concepts suggested.

It must be emphasized that the way the Technological Capability Model was built and determined, as well as the names and concepts attributed to the two phenomena were entirely based on this study. Errors and interpretations are the sole responsibility of the authors.

From the study it is possible to make some suggestions of some research possibilities on the internationalization of firms and the evolution of technological capabilities:

i. to search for other cases, qualitatively, in order to verify if the same phenomenon occurs similarly;

ii. to deepen this research with a larger number of companies studied for possible quantitative analysis;

iii. to develop studies in soluble coffee companies installed in other countries, to examine whether the phenomenon occurs with non-Brazilian companies; 
iv. to study the issues of internationalization and technological capacity of enterprises with other perspectives, interpretations and theories to analyze the results;

v. to perform comparative case studies among soluble coffee companies with the same analytical framework;

vi. to deepen this study to determine the reasons why this company did not succeed in the complete evolution of its technological capabilities in the different technological functions proposed and understand the factors that may lead to speed the rate of accumulation of technological capabilities.

\section{References}

ANDERSEN, O.; Buvik, A.(2002) Firm's internationalization and alternative approaches to the international customer/ market selection. International Business Review, I I, 347-363

ANDERSSON, S. (2000) The internationalization of the firm from an entrepreneurial perspective. International Studies of Management \& Organization, 30 (I), 63-92

ARIFFIN, N.; Bell, M. (1999) Firms, Politics and Political Economy: Patterns of Subsidiary-Parent Linkages and Technological Capability-building in Electronics TNC Subsidiaries in Malaysia, in Jomo, K.S.; Felker, G.; Rasiah, R. (Eds), Industrial Technology Development in Malaysia, Routledge, UK , PP I50-190

ARIFFIN, N.; Figueiredo, P. N.(2004) Internationalization of innovative capabilities: counter-evidence from the electronics industry in Malaysia and Brazil. Oxford Development Studies, 32 (4), 559-583

BELL, M. Pavitt, K. (1982) The development of technological capabilities. In: UI Haque, I.; Bell, M. Technical change in infant industries: a review of the empirical evidence. SPRU, Brighton

BELL, M. Pavitt, K. (1993) Technological accumulation and industrial growth: contrast between developed and developing countries. Industrial and Corporate Change, 2 (2), 157- 210

BELL, M.; Pavitt, K. (1995) The Development of Technological Capabilities. In: I. U. Haque (ed.), Trade, Technology and International Competitiveness. The World Bank, Washington DC

BELL, M.; Larsson, R;Westphal, L.E. (I 984) Assessing the Performance of Infant Industries. World Bank Staff Working Papers n. 666. The World Bank, Washington

BENITO, G. R. G.; Gripsrud, G. (1992) The expansion of foreing direct investment: discrete rational location or a cultural learning process? Journal of International Business Studies, $23(3), 46 I-476$

BUCKLEY, P. J.; Casson, M. (1988) The limits of explanation: testing the internalization theory of the multinational enterprise. Journal of International Business Studies, 19 (2), $181-193$

CHEN, L. C. (2009) Learning through informal local and global linkages: The case of Taiwan's machine tool industry, Research Policy 38(3): 527-535.

CHUANG, Y-S. (2008), The development of absorptive capacity in latecomer firms: Case studies from the Taiwanese

TFT-LCD industry; DPhil Thesis, SPRU-Science and Technology Policy Research, University of Sussex, Brighton, UK.

DAHLMAN, C., Westphal, L. (1982) Technological effort in industrial development: an interpretative survey of recent research. In: STEWART, F; JAMES, J. (Ed.). The economics of new technology in developing countries. France Pinter, London, pp. 105-137.

DANTAS, E.; Bell, M. (2009) Latecomer firms and the emergence and development of knowledge networks:The case of Petrobras in Brazil. Research Policy, 38, 829-844

DANTAS, E.; Bell, M. (20II) The Co-Evolution of FirmCentered Knowledge networks and Capabilities in Late Industrializing Countries:The Case of Petrobras in the Offshore Oil Innovation System in Brazil. World Development, doi:10.1016/j.worlddev.2011;02;002

DENZIN, N. K. (1978); The Research act; McGraw-Hill, New York

DIB, L. A.; Carneiro, J. Avaliação Comparativa do Escopo Descritivo e Explanatório dos Principais Modelos de Internacionalização de Empresas. In: Anais do XXX ENANPAD. Salvador:ANPAD, 2006."

DUNNING, J. H. (2000) The eclectic paradigm as an envelope for economic and business theories of MNE activity. International Business Review, 9, 163-190

DUNNING, J. H. (200I) The eclectic paradigm of international production: past, present, and future. International Journal of the Economics of Business, 8 (2), 173-190

EISENHARDT, K. M. (1989); Building Theories From Case Study Research. Academy of Management, I4(4), 532 - 550

ISSN: 07 I8-2724. (http://www.jotmi.org)

Journal of Technology Management \& Innovation (C) Universidad Alberto Hurtado, Facultad de Economía y Negocios. 
ENOS, J. L., The creation of technological capability in developing countries. Pinter Publishers, London

FIGUEIREDO, P. N. (200I) Technological Learning and Competitive Performance. Northampton, USA. Edward Elgar

FIGUEIREDO, P. N. (2003) Aprendizagem Tecnológica e Performance Competitiva. Rio de Janeiro, Editora FGV, 2003.

FIGUEIREDO, P. N. (2010) Discontinuous innovation capability accumulation in latecomer natural resource-processing firms. Technological Forecasting \& Social Change, 77, 1090-1108

HOBDAY, M. (1995) Innovation in East Asia: the challenge to Japan.Aldershot: Edward Elgar

HOBDAY, M.; Rush, H. (2007) Upgrading the technological capabilities of foreign transnational subsidiaries in developing countries: The case of electronics in Thailand, Research Policy 36(9): I335-1356.

HYMER, S.(1976) The international operations of national firms: a study of direct foreign investment. Doctorate Thesis, Cambridge, MA:The MIT Press

IANSITI, M.; Clark, K. (1994) Integration and dynamic capability: evidence from product development in automobiles and mainframe computers, Industrial and Corporate Change, 33: 557-605.

JICK,T. D. (1979) Mixing Qualitative and Quantitative Methods:Triangulation in Action. Administrative Science Quartely, $24(4), 602-611$

JOHANSON. J.; Vahlne, J. (1977) The internationalization process of the firm: a model of knowledge development and increasing market commitment. Journal of International Business Studies, 8, 23-32,

JOHANSON, J.;Vahlne, J.(1990) The Mechanism of Internationalization. International Marketing Review, v.7, n.4, I I-24

JOHANSON, J.; Wiedersheim-Paul, F. (1975) The internationalization of the firm: Four Swedish Cases. Journal of Management Studies, 12 (3), 305-322

KARAOZ, M.;Albeni, M. (2005) Dynamic technological learning trends in Turkish manufacturing industries. Technological Forecasting \& Social Change, 72, 866-885

KATZ, J. (1976) Importación de tecnología, aprendizaje y industrialización dependiente. México: Fondo de Cultura Económica
KIM, L. (1993) National system of industrial innovation: dynamics of capability building in Korea. In: nelson, R. R. (ed.) National Innovation Systems: a Comparative Analysis. New York : Oxford University Press

KIM, L. (1997) The dynamics of Samsung's technological learning in semiconductors. California Management Review,39 (3), 86- 100

KOGUT, B. International International Management and Strategy. In: Pettigrew, A.;Whittington, R. (Ed.). Strategy and Management. London, Sage Publications, 26I-278.

KRAUS, P.G. (2006) O Processo de Internacionalização das Empresas: o caso brasileiro. Revista de Negócios, Blumenau, II (2), 25-47

LALL, S.(1980) Monopolistic Advantages and Involvement by U.S. Manufacturing Industry. Oxford Economic Papers (New Series), 32 (I)

LALL, S. (1992) Technological Capabilities and Industrialization.World Development, 20(2): 165- 186

LEONIDOU, L.; KATSIKEAS, C.; SAMIEE, S..(2002) Marketing strategy determinants of export performance: a metaanalysis. Journal of Business Research, 55 (I), 5I-67

MARCELLE, G. (2005) How do Telecom firms build capabilities? Lessons from Africa. Telecommunications Policy, 29, 549-572

MOLERO, J., M. Buesa; Fonfría, A. (1998) The Internationalization of SMEs Innovatory Firms in the Southern European Economies. Conference. In: EU Integration in the Context of Globalization. London, South Bank University

NAM, K. (20II) Learning through the international joint venture: lessons from the experience of China's automotive sector. Industrial and Corporate Change, 20 (3), 855-907

OVIATT, B.; McDougall, P. (1999) A framework for understanding accelerated international entrepreneurship. In: Rugman, A.; Wright, R. (eds.) Research in global strategic management: international entrepreneurship. Stamford, JAI Press Inc. $23-40$

PAVITT, K. (199I) Key Characteristics of the Large Innovating Firm. British Journal of Management, 2, 4I-50

PENROSE, Edith. (1959) The Theory of the Growth of the Firm. Oxford, Basil Blackwell 
PRAHALAD, C.; Hamel, G. (1990) The Core Competence of the Corporation. Harvard Business Review, 90 (3), 79-9I.

PRASHANTHAM, S. (2005) Toward a Knowledge-Based Conceptualization of Internationalization. Journal of International Entrepreneurship, 3 (I)

REICHERT, F. M.; Beltrame, R. S.; Corso, K. B.; Trevisan, M.; Zawislak, P. A. (20II) Technological Capability's Predictor Variables. Journal of Technology Management \& Innovation, $6($ (I), $14-25$

ROUSSEVA, R. (2008) Identifying Technological Capabilities with Different Degree of Coherence: the challenge to achieve high technological sophistication in latecomer software companies (based on the Bulgarian case) Technological Forecasting and Social Change 75(7): 1007-103I.

RUGMAN, A. M. (1980) A New Theory of the Multinational Enterprise: Internationalization Versus Internalization. Columbia Journal of World Business, I5 (I)

SCOTT-KEMMIS, D. (1988) Learning and the accumulation of technological capacity in Brazilian pulp and paper firms. World Employment Programme Research, Working Paper $n^{\circ} 187,2-22$

TEECE D., Pisano G. And Shuen A. (1997) Dynamic capabilities and strategic management. Strategic Management Journal, 18 (7), 509-533.

VERNON, R. (1966) International investment and international trade in the product cycle. Quarterly Journal of Economics, $80,190-207$

VERNON, R. (1979) The product cycle hypothesis in a new international environment. Oxford Bulletin of Economics and Statistics, 4 I (4), 255-267

WELCH, L. S.; Luostarinen, R.: (1988) Internationalization: Evolution of a Concept. Journal of General Management, 14 (2)

WESTPHAL, L. E.; KIM, L.; DAHLMAN, C. J. (1984) Reflections of Korea's acquisition of technological capability. Washington, DC: World Bank Research Department, Economics and Research Staff (Report DRD77).

XIE, X (2004) Technological learning in China's colour TV (CTV) industry. Technovation, 24, 499-5I 2.
XIE,W.;Wu, G. (2003) Differences between learning process in small tigers and large dragons: Learning processes of two colors TV (CTV) firms within China. Research Policy, 32, |463-1479

YIN, R. K. (2005) Estudo de caso: planejamento e métodos; Porto Alegre, Bookman 
J.Technol. Manag. Innov. 2012,Volume 7, Issue 2

ISSN: 07I8-2724. (http://www.jotmi.org)

Journal of Technology Management \& Innovation @ Universidad Alberto Hurtado, Facultad de Economía y Negocios. 